\title{
Implications of the financial crisis on the soundness of the banking system in the Republic of Moldova
}

\author{
Clichici, Dorina
}

Gribincea, Corina

- RECEIVED : 6 maY 2014

- ACCEPTED : 7 JULY 2014

\section{Abstract}

The extent of recent financial crisis implications on economies differs from country to country. The effects of the crisis events in developed countries differ from the effects in developing countries. The banking systems are now more vulnerable to shocks and to contagion than ever before due to the globalization of banking activity. In recent years, the Moldovan banking system has demonstrated a high degree of resilience to the global financial crisis. The local banking system has a low degree of connectivity to the European and world banking systems due to a very limited presence of international banks in the market. This has meant that there has been no direct contagion during the last financial crises. The effects of the crises in Moldova were felt indirectly by the banks, through the channel of remittances and foreign trade, which have diminished substantially as a result of the economic decline in Europe, particularly in 2009. This article aims to verify whether a systemic crisis was recorded within the domestic banking sector during recent years and to establish the conditions which could be classified as a full-fledged crisis episode in the case of the Republic of Moldova. In addition, the implications of the recent financial crisis on the soundness of Moldova's banking system are identified.

\section{Keywords:}

Banking crisis, Policy interventions, Banking system, Financial soundness indicators.

\section{JEL classification:}

E52, G01, G21.

Clichici, D. National Institute for Economic Research of Academy of Sciences of Moldova (NIER). 45, Ion Creanga street. Chisinau, Republic of Moldova. www.ince.md.7) +3732250 - I I- 06. E-mail:dorina.clichici2@gmail.com

Gribincea, C. National Institute for Economic Research of Academy of Sciences of Moldova (NIER). 45, Ion Creanga street. Chisinau,

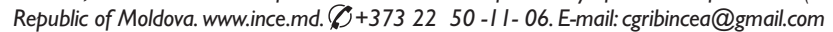




\title{
Implicaciones de la crisis financiera en la solidez del sistema bancario de la República de Moldavia
}

\author{
Clichici, Dorina
}

Gribincea, Corina

\section{Resumen}

La profundidad de las consecuencias de la reciente crisis financiera en las distintas economías difiere de un país a otro. Sus efectos no son los mismos en los países desarrollados y en los países en desarrollo. La globalización de la actividad bancaria tiene como consecuencia que los sistemas bancarios sean, ahora más que nunca, más vulnerables a los shocks y al contagio. El sistema bancario moldavo ha demostrado durante los últimos años un alto grado de resiliencia a la crisis financiera mundial. Tiene un bajo grado de conectividad con el sistema bancario europeo y mundial debido a la muy baja presencia de bancos internacionales en el mercado, lo cual ha sido determinante en el hecho que no haya habido contagio directo en las últimas crisis financieras. Los efectos de las crisis en Moldavia afectaron a los bancos de forma indirecta, vía remesas y comercio exterior, que han disminuido sustancialmente como resultado de la ralentización de las economías europeas, en particular en 2009. El objetivo del artículo es verificar si ha tenido lugar una crisis sistémica el sector bancario moldavo en los últimos años, así como determinar, en el caso de la República de Moldavia, las condiciones que pueden ser calificadas de episodio de crisis en toda regla. También hay se identifican las implicaciones de la reciente crisis financiera en la solidez del sistema bancario moldavo.

\section{Palabras clave:}

Crisis bancaria, intervenciones de política, sistema bancario, indicadores de solidez financiera. 


\section{Introduction}

Banking systems are now more vulnerable to shocks and to contagion than ever before due to the globalization of banking activity. The banking crises prompted numerous research papers and case studies, some descriptive and some econometric, of specific banking crisis episodes, as well as several attempts to draw generalizations from individual experiences. Some examples of case studies include Garcia-Herrero (1997), Drees and Pazarbasioglu (1998), Jaramillo (2000), González-Hermosillo et al. (1997), Ramos (1998), and Schumacher (2000). Among papers drawing general lessons, see Davis (1995), Gavin and Hausman (1995), Goldstein and Turner (1996), Mishkin (1996), Rojas-Suárez and Weisbrod (1995), and Sheng (1995).

The extent of crisis implications on economies differs from country to country. The effects of the crisis events in developed countries differ from the effects in developing countries. The main implications of a systemic banking crisis in a country are noted when its financial and banking industry experiences a significant number of defaults, while financial entities face enormous problems fulfilling financial contracts on time (Contessi and El-Ghazaly, 2011). As a consequence, a country experiences a large increase in nonperforming loans, and a large decrease in the capital in the banking system. Sometimes, these events follow a fall in asset prices (for example, in the real estate market) and sometimes overlap with runs on banks, but in order to be defined as "systemic", such crises must involve a large number of institutions or cover a large portion of the banking system. If the beginning of a banking crisis is marked by bank runs and withdrawals, then changes in bank deposits could be used to date the crises (Kaminsky and Reinhart, 1999). Often, the banking problems do not arise from the liability side, but from a protracted deterioration in asset quality, be it from a collapse in real estate prices or increased bankruptcies in the nonfinancial sector. In such cases, changes in asset prices or a significant increase in either bankruptcies or nonperforming loans could be used to mark the onset of the crisis.

Banking crises, a distinct subset of financial crises, consist either of panics, moments of temporary confusion about the unobservable incidence across the financial system of observable aggregate shocks, or severe waves of bank failures which result in aggregate negative net worth of failed banks in excess of one percent of GDP (Calomiris, 2009). Unlike financial crises, however, historical evidence suggests that banking crises cannot be seen as an inevitable result of human nature or the liquidity transforming structure of bank balance sheets, and adverse macroeconomic circumstances alone are not sufficient to produce banking crises. 
A banking crisis is defined as systemic if two conditions are met (Laeven and Valencia, 2012):

1. Significant signs of financial distress in the banking system (as indicated by significant bank runs, losses in the banking system, and/or bank liquidations);

2. Significant banking policy intervention measures in response to significant losses in the banking system.

Demirgüç-Kunt and Detragiache (2005) established that for an episode of distress to be classified as a full-fledged crisis, at least one of the following four conditions had to hold:

1. The ratio of nonperforming assets to total assets in the banking system exceeded $10 \%$;

2. The cost of the rescue operation was at least $2 \%$ of GDP;

3. Banking sector problems had led to a large scale nationalization of banks;

4. Extensive bank runs took place or emergency measures such as deposit freezes, prolonged bank holidays, or generalized deposit guarantees were enacted by the government in response to the crisis.

Policy interventions in the banking sector are significant if at least three out of the following six measures have been used (Laeven and Valencia, 2012):

1. Extensive liquidity support ( $5 \%$ of deposits and liabilities to nonresidents);

2. Bank restructuring gross costs (at least $3 \%$ of GDP);

3. Significant bank nationalizations;

4. Significant guarantees put in place;

5. Significant asset purchases (at least $5 \%$ of GDP);

6. Deposit freezes and/or bank holidays.

None of the episodes of distress suggested by Demirgüç-Kunt and Detragiache (2005) were recorded within the banking system of the Republic of Moldova. Policy interventions in the Moldovan banking sector were insignificant during the crisis period. None of the interventions specified by Laeven and Valencia (2012) were used by the National Bank during the last years in the Republic of Moldova.

The paper is organized as follows. Section 2 describes the banking system characteristics in the Republic of Moldova. Section 3 verifies whether there has recently been a systemic crisis in the Republic of Moldova's banking sector. Section 4 analyzes the implications of the crisis on the soundness of the Moldovan banking system. Section 5 details the main conclusions. 
The Republic of Moldova is a small country with a financial sector dominated by the banking system: it accounted for $93 \%$ of total financial assets and $96 \%$ of total loans provided by the financial sector at 2012 year-end (World Bank, 2013). The number of banking institutions during the years 2006-2013 remained broadly unchanged, with 14 commercial banks.

Concentration ratios of the Moldovan banking system range between $60-70 \%$ for the largest five banks in the system. Although foreign participation within the local banking industry is considerable (the share of foreign investments in banks' capital recorded at the end of 2013 was $72.2 \%$ ), the majority of foreign holdings in the Republic of Moldova belong to investors that are not internationally highly-rated financial institutions. A significant percentage of the banks' owners are residents in offshore centers. Foreign strategic investors ${ }^{1}$ own less than $20 \%$ of the banking sector's assets (see appendix $A$ ).

One of the largest Moldovan banks - Moldova Agroindbank - has been recognized many times as one of the World's Best Emerging Market Banks and World's Best Foreign Exchange Providers by Global Finance (2013, see Table 1 ). These awards further prove the domestic banking system's resilience to the recent crisis.

Table 1. Soundness of the domestic banking system, by Global Finance rankings and awards

\begin{tabular}{llllll}
\hline \multicolumn{2}{l}{ I. World's Best Emerging } & Market Banks & \multicolumn{3}{l}{ II. World's Best Foreign } \\
\hline Year & Level & Bank name & Year & Level & Bank name \\
\hline 2012 & $\begin{array}{l}\text { Western } \\
\text { Europe }\end{array}$ & $\begin{array}{l}\text { Moldova } \\
\text { Agroindbank }\end{array}$ & 2013 & $\begin{array}{l}\text { Western } \\
\text { Europe }\end{array}$ & $\begin{array}{l}\text { Moldova } \\
\text { Agroindbank }\end{array}$ \\
\hline 2011 & National & $\begin{array}{l}\text { Moldova } \\
\text { Agroindbank }\end{array}$ & 2012 & $\begin{array}{l}\text { Western } \\
\text { Europe }\end{array}$ & $\begin{array}{l}\text { Moldova } \\
\text { Agroindbank }\end{array}$ \\
\hline 2010 & Global & $\begin{array}{l}\text { Moldova } \\
\text { Agroindbank }\end{array}$ & 2011 & Global & $\begin{array}{l}\text { Moldova } \\
\text { Agroindbank }\end{array}$ \\
\hline 2009 & National & $\begin{array}{l}\text { Moldova } \\
\text { Agroindbank }\end{array}$ & 2010 & Global & $\begin{array}{l}\text { Moldova } \\
\text { Agroindbank }\end{array}$ \\
\hline & & 2009 & National & $\begin{array}{l}\text { Moldova } \\
\text { Agroindbank }\end{array}$ \\
\hline
\end{tabular}

SOURCE: GLOBAL FINANCE (2013), COUNTRY ECONOMIC REPORTS \& GDP DATA, MOLDOVA

${ }^{1}$ B.C. "Mobiasbancă - Groupe Société Générale” S.A., B.C. “EXIMBANK-Gruppo Veneto Banca” S.A., B.C. ProCredit Bank S.A., B.C.R. Chi $\square$ inău S.A. 
The local banking system has a low degree of connectivity to the European and world banking systems due to a very limited presence of international banks in the market ${ }^{2}$. This has meant that there has been no direct contagion within the last financial crises (Table 2).

Table 2. Foreign strategic investors in the banking system

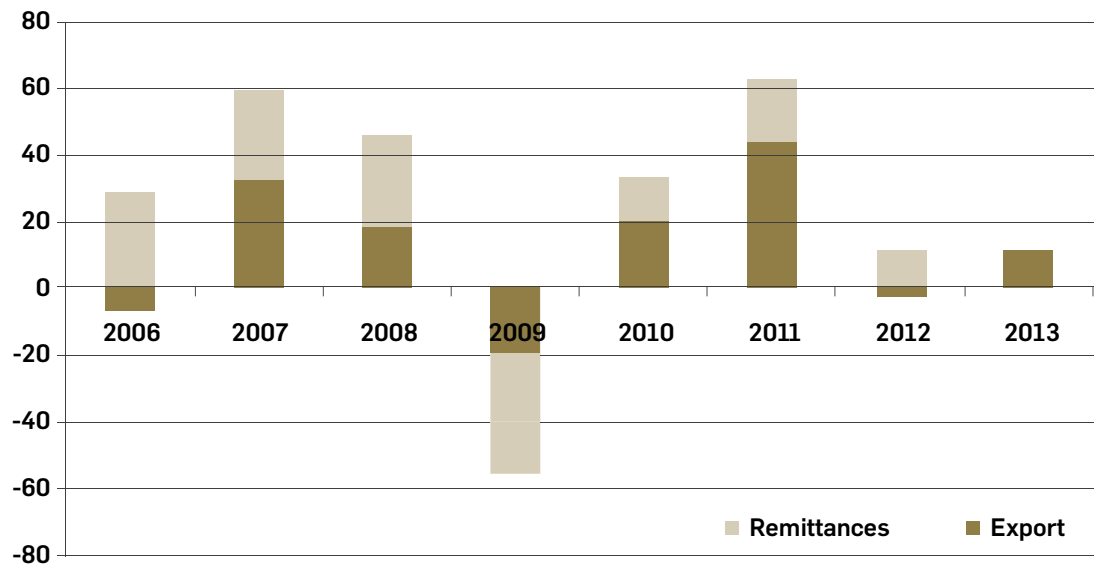

SOURCE: AUTHORS' ELABORATION

At present, Moldova's banking sector is developing in terms of geographical accessibility. During the 2006-2013 period, statistical data reflect a trend of expansion in territorial units and the number of people employed in the domestic banking sector. The number of banking divisions increased from 2006 to 2013, reaching 1288 units at the end of 2013 compared to 966 units in 2006 (with 2009 as an exception). During the 2006-2012 period, the number of branches per 100,000 adults increased from 8 units in 2006 to 12 in 2012. The indicators of banking services accessibility are close to those of the Commonwealth of Independent States (CIS) country indicators, however, there is a big gap compared to Central and Eastern European countries (Table 3).

Table 3. The indicators of accessibility of banking institutions/services, 2011 year-end

\begin{tabular}{lccc}
\hline & $\begin{array}{c}\text { Central and } \\
\text { Eastern Europe }\end{array}$ & $\begin{array}{c}\text { CIS } \\
\text { countries }\end{array}$ & $\begin{array}{c}\text { Republic of } \\
\text { Moldova }\end{array}$ \\
\hline Branches $\left(1000 \mathrm{~km}^{2}\right)$ & 22 & 7 & 10 \\
\hline ATM $\left(1000 \mathrm{~km}^{2}\right)$ & 44 & 18 & 26 \\
\hline $\begin{array}{l}\text { Open deposit accounts at commercial banks } \\
\text { per } 1,000 \text { adults) }\end{array}$ & 1726 & 1935 & 1483 \\
$\begin{array}{l}\text { Open credit accounts at commercial banks } \\
\text { per } 1,000 \text { adults) }\end{array}$ & 492 & - & 46 \\
\hline
\end{tabular}

SOURCE:AUTHOR'S ELABORATION BASED ON IMF DATA, FINANCIAL ACCESS SURVEY (HTTP://FAS.IMF.ORG/) $\square$

${ }^{2}$ Of the 14 commercial banks operating in the local banking market, there are only 4 with 100\% foreign capital. 
The number of deposit and credit accounts opened at commercial banks is quite low compared to Central and Eastern Europe countries, where open credit accounts at commercial banks (per 1,000 adults) reached 492 accounts in 2011, compared to 46 accounts in the Republic of Moldova. The number of ATMs increased by $20 \%$ in 2011 and the number of deposit accounts has increased by $13 \%$ since $2007^{3}$.

\section{Checking for a systemic crisis in the Republic of Moldova banking system}

In order to verify whether a systemic crisis was recorded within the Republic of Moldova banking sector in recent years, we will establish the above-mentioned conditions for the case of the Republic of Moldova. We will then identify the implications of the recent financial crisis on the soundness of Moldova's banking system.

According to Demirgüç-Kunt and Detragiache (2005) the ratio of nonperforming assets-to-total assets in the banking system should exceed $10 \%$ in order to classify as a full-fledged crisis episode. In the case of Moldova's banking system this ratio did not reach the 10\% level between 2007 and 2013, even though the total amount of assets continuously increased (see Figure 1).

Figure 1. Nonperforming assets-to-total assets and total assets of Moldova's banking system

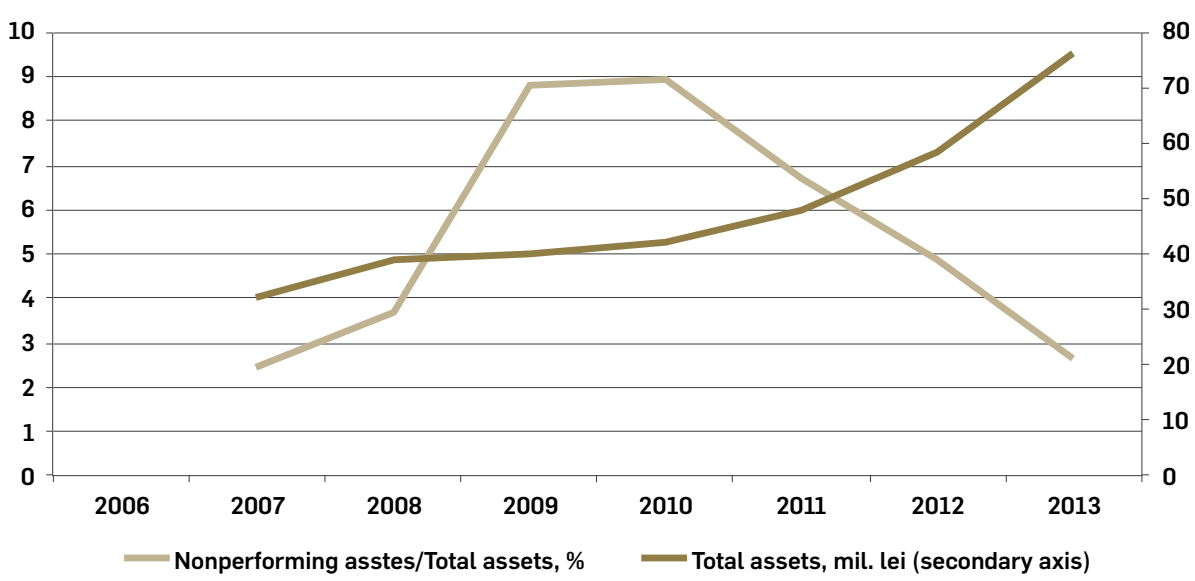

SOURCE: NATIONAL BANK OF MOLDOVA DATABASE, 2007-20I3

None of the other episodes of distress suggested by Demirgüç-Kunt and Detragiache (2005) were recorded within the Republic of Moldova banking system: there were

${ }^{3}$ IMF Financial Access Survey (http://fas.imf.org/) 
no significant rescue operations by regulatory authorities; some problems were recorded within the banking sector but they did not lead to nationalization of banks; there were no recorded bank runs or emergency measures such as deposit freezes, prolonged bank holidays, or generalized deposit guarantees. Furthermore, policy interventions in the Moldovan banking sector were insignificant. None of the interventions specified by Laeven and Valencia (2012) were used in recent years by the National Bank of Moldova. The most important interventions in the Moldovan banking sector were those regarding the minimum capital adequacy ratio and the minimum reserve requirements. In June 2012, the minimum capital adequacy ratio was raised by the National Bank of Moldova to $16 \%$; up until then it had been at $12 \%$.

The National Bank of Moldova continued to work towards ensuring broad monetary conditions to create conditions for encouraging both loan supply and demand in order to stimulate sustainable economic growth. Due to excess liquidity recorded in the banking system in recent years, the Central Bank has taken measures more oriented towards offer contraction. Thus, there has been a gradual increase of the minimum reserve requirements rate up to $14.0 \%$ at 2012 base (NBM, 2012), taking into consideration the passivity on the interbank money market, which aims to improve the quantitative and qualitative indicators and the transmission mechanism ${ }^{4}$.

During this period, only positive values were recorded for banks' net liquidity position and the Central Bank generally acted in a debtor position with regard to the banking system, continuing the sterilization operations. Despite the Central Bank's interventions, the positive trend of the credit granted to the private sector was influenced by a number of factors: 1) the favorable statistical effect of inflation which remained close to the target set by the Central Bank (for the first time in 20 years the annual rate of inflation was in single figures for 3 consecutive years, close to $5 \%$ ); 2 ) improved sustainability of maintaining the inflation within the variation range around the annual targets, creating favorable conditions for sustainable economic growth in the Republic of Moldova and bringing benefits for both investors and the general population.

Thus, the situation within Moldova's banking system could not be classified as a fullfledged crisis. However the recent financial crisis has been felt indirectly by the real economy in general and by the banking industry in particular.

${ }^{4}$ Rate evolution of minimum required reserves: January to June 2009- 17.5\%; June to July $2009-16 \%$; August 2009-8\%, 2010$8 \%$; February 201 I- increased from $8 \%$ to II\%; in July 2011 - $14 \%$ to present date. 
The effects of the crises in Moldova were felt indirectly by the banks, through the channel of remittances and foreign trade, which have diminished substantially as a result of the economic decline in Europe, particularly in 2009. The decline of private consumption in the Euro area as a result of the crisis has contributed to a sudden decrease in Moldovan exports to the EU and in the volume of remittances in 2009 and 2012 (see Figure 2).

\section{Figure 2. Growth rate of remittances and exports (\%), Moldova, 2006-2013}

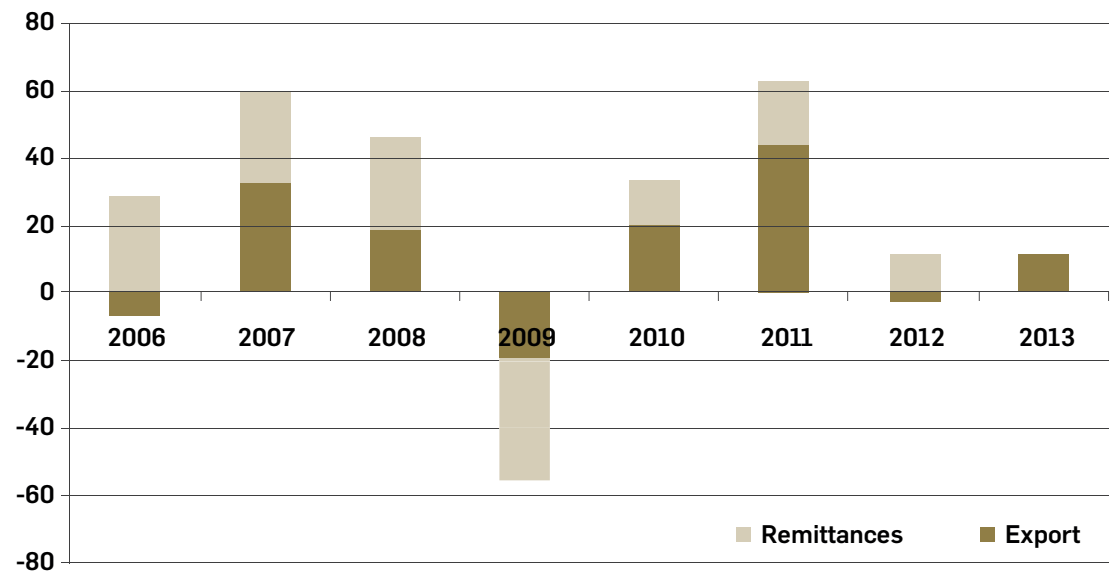

SOURCE: AUTHORS' ELABORATION, NATIONAL BANK OF MOLDOVA DATABASE, 2006-20I3

Although remittances have declined, Moldova's dependence on them is one of the highest in the world (24.5\% of GDP in 2012): Moldova ranked fifth internationally (World Bank, 2013) in 2012. This exacerbates the financial system's vulnerability to potential volatility in these inflows. The main determinant of fragility is the dependence on the economic conditions of the main destinations for Moldovan emigrants (Russia and the EU). Along with worsening conditions in destination countries, the inflow of remittances has slowed down considerably. This puts the exchange rate under pressure and reduces the availability of financial resources to the financial sector. It also increases credit risk, as part of bank lending is based on the borrowers earning/receiving remittances.

\section{Implications of the crisis on the soundness of the Moldovan banking system}

The main implications of the crisis on the soundness of the banking system can be identified by assessing the evolution of financial soundness indicators of the system (capital adequacy and liquidity ratio, assets quality, profitability), and the evolution of some structural development indicators. 


\subsection{Evolution of financial soundness indicators of the banking systems}

\section{Capital adequacy and liquidity}

A better capitalized banking system helps to reduce possible contagion effects from individual bank failures in the same country or region. The average capital adequacy and liquidity ratio of Moldova's banking system recorded for 2006-2013 indicates a high degree of bank safety and the ability to perform risky operations without affecting the capital (see Figure 3).

\section{Figure 3. Capital adequacy and current liquidity ratio ${ }^{5}(\%)$}

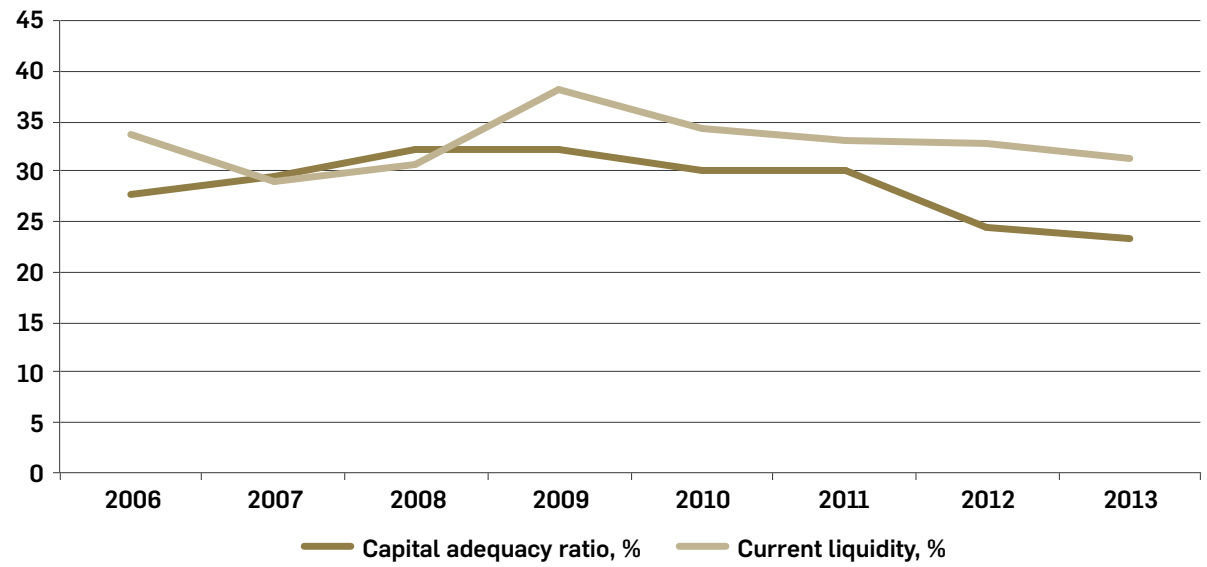

SOURCE: NATIONAL BANK OF MOLDOVA DATABASE, 2006-20I3

Nevertheless these indicators decreased slowly after 2009. Thus the effects of the global financial crisis were felt by the Moldovan banking system, even if the capital and liquidity ratios were significantly higher than the Basel requirements and the values required by the National Bank of Moldova ${ }^{6}$. Degryse et al. (2013) suggests that increases in capital do have an effect in reducing bank fragility but only when capital levels are higher than a threshold of around 7\%. Taking into consideration the higher values of capital and liquidity ratios in Moldova we could assume that the banking system is relatively resilient to the crisis.

Among Eastern Partnership countries and some EU countries of a similar size and with similar economic problems, Moldova has the highest level of capitalization and liquidity (see Figure 4).

\footnotetext{
${ }^{5}$ Current liquidity $=$ Liquid assets $/$ Total assets.

${ }^{6}$ Since June 20I2, the minimum capital adequacy ratio established by the National Bank of Moldova has been I6\%, up until then it was $12 \%$. The current minimum liquidity ratio is $20 \%$.
} 
Figure 4. Bank liquid reserves-to-bank assets, Bank Regulatory Capital-to-RiskWeighted Assets (\%), International comparison: Eastern Partnership countries and some EU countries, average rates for 2009-2012

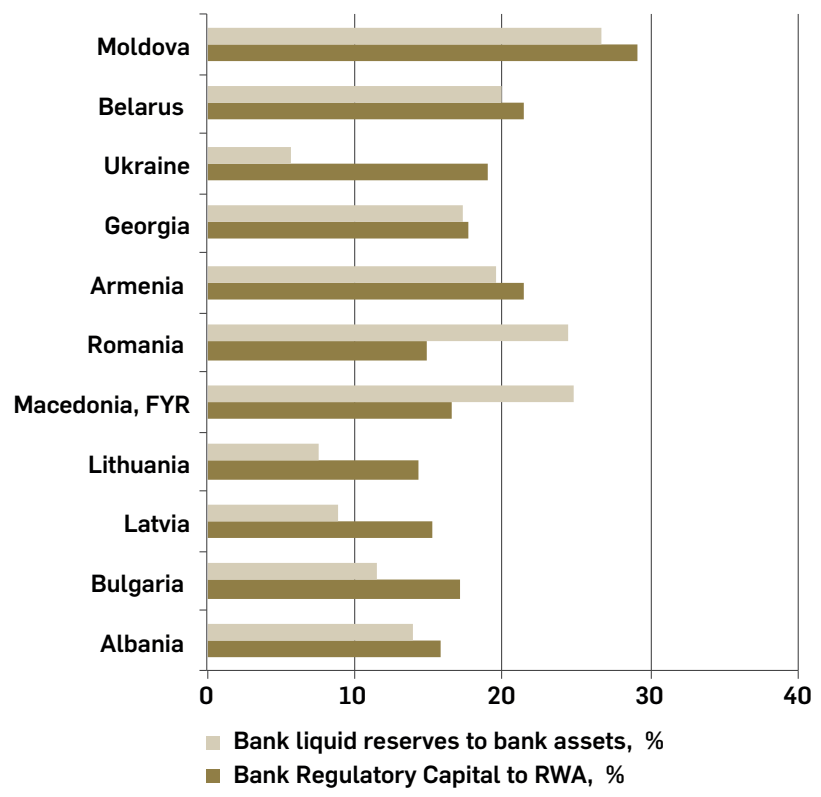

SOURCE:WORLD BANK AND IMF DATA BASE, FINANCIAL SOUNDNESS INDICATORS TABLES 2009-20I3

The recent financial crisis has shown that banks' funding structure is key to their resilience. Banks can finance themselves with both depository funding and wholesale funding (i.e. funding from other banks, money market funds, corporate treasuries and other non-bank investors). Those relying mostly on wholesale funding have been severely affected by the crisis. Banks in Australia and Canada, for example, have been very resilient to the crisis because they rely mostly on depository funding, much of which comes from retail sources such as households (Degryse et al., 2013). Reliance on non-core deposits as a funding source, wholesale funding, could prove to be a more volatile source of funding and one that may intensify regional banking fragility.

Moldovan banks have demonstrated a high level of resilience to the last financial crisis due to their funding structure. They finance themselves with both depository funding and wholesale funding, but they rely mostly on depository funding. The deposits-toliabilities ratio reached $85.4 \%$ at the end of 2013 , much of which came from retail sources (Figure 5). Figure 4 suggests that banks have a strong preference for maintaining liquidity. This is mostly due to the uncertain macroeconomic outlook and the recent history of banking sector instability.

In 2009, a sudden drop in the deposits-to-liabilities ratio was recorded, as a result of remittances and trade revenues decreasing. Another indicator - the loans-to-deposits 
ratio - recorded a sharp fall from 2007 to 2009, and still remains at a low level. These tendencies suggest that Moldovan banks have a strong preference for maintaining liquidity during the financial crisis. This is mostly due to the uncertain macroeconomic outlook and the recent history of banking sector instability.

\section{Figure 5. Funding structure of Moldova's banking system (\%), at year-end}

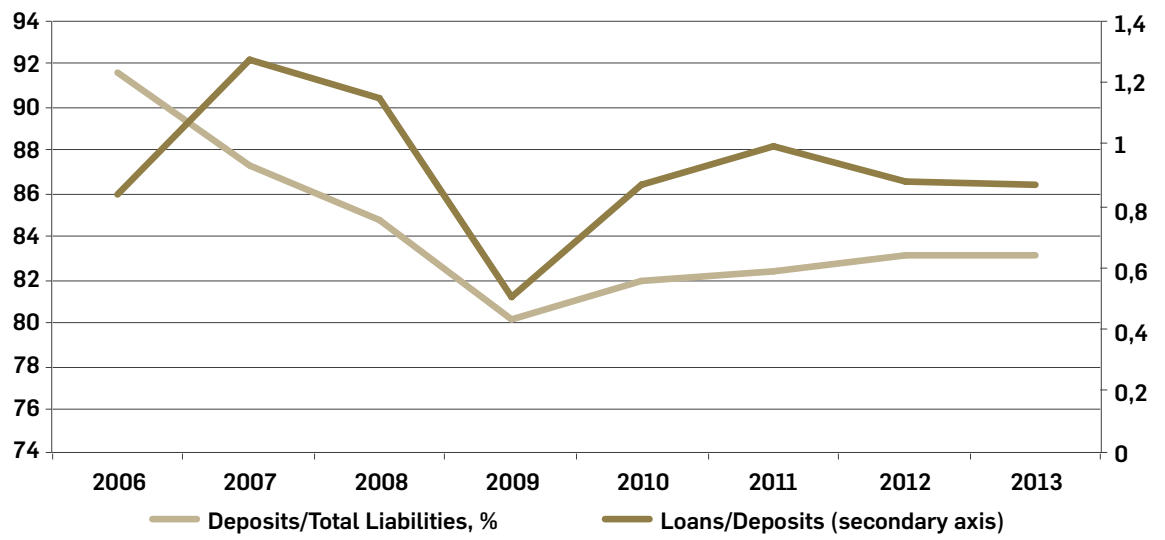

SOURCE: NATIONAL BANK OF MOLDOVA DATABASE, 2006-20I3

Assets quality

The general effect of the recent financial crises on the Moldovan banking system was felt on the banks' asset side. The crisis events have negatively affected the creditworthiness of Moldovan borrowers and thus the quality of local banks' loan portfolios. An alarming feature of the domestic banking sector is the high level of bad loans $(14.5 \%$ in 2012). Economic contraction in 2009 due to the global financial crisis caused a significant increase in nonperforming loans (substandard, doubtful and loss) as a percentage of the total loan portfolio, from $5.9 \%$ in 2008 to $16.3 \%$ in 2009 (Figure 6).

Figure 6. Nonperforming loan ratio and provision for loan losses ratio (\%)

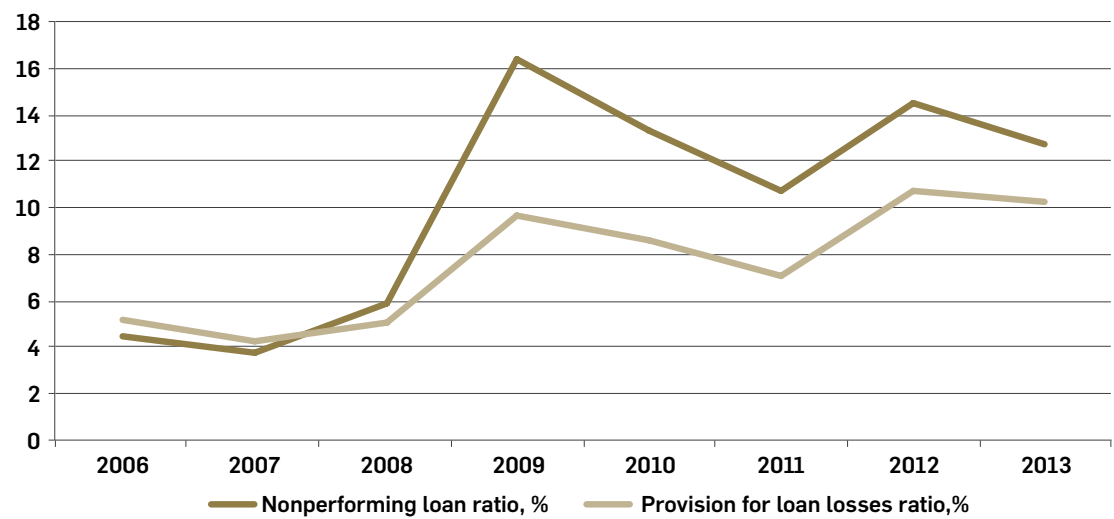


The sudden increase of credit risk during this period led banks to restrict lending and to significantly increase the allowances for loan losses. With few exceptions, the trend of deterioration in loan quality continued to be a common feature of the European banking market in 2012 due to the sovereign debt crisis.

The Moldovan banking system is highly sensitive to macroeconomic changes and expectations, showing a pro-cyclical character. Given the pro-cyclical nature of the banking system, the relatively favorable macroeconomic situation in Moldova recorded in 2013 was fully reflected in increased banking credit activity (Figure 7). While this credit growth is from a very low economic base, possibly reflecting catchup growth, a continued increase will require careful attention to preempt any deterioration in banks' credit portfolios.

Figure 7. Growth rate of new credits granted by banks and GDP in the Republic of Moldova (\%), 2006-2013

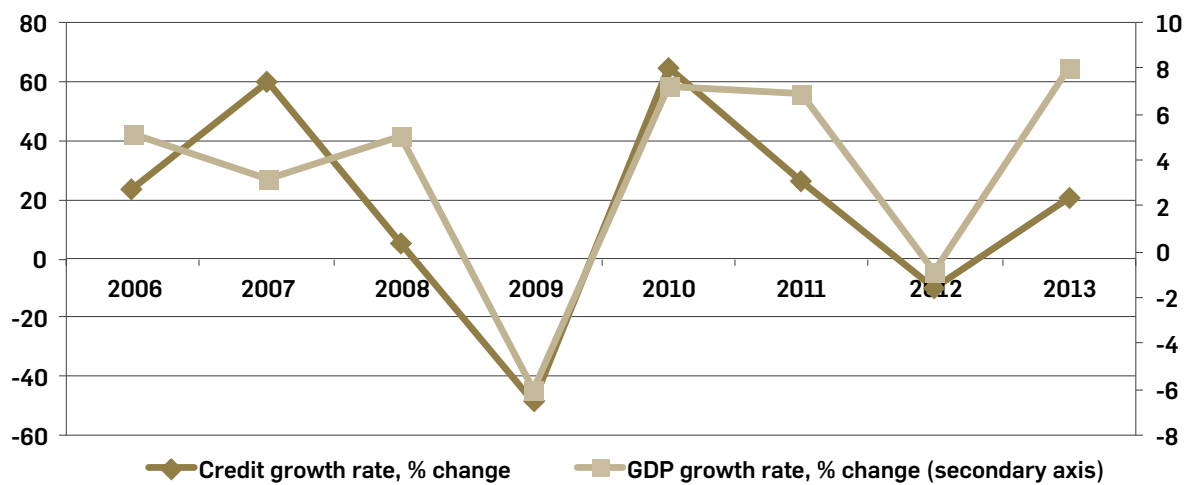

SOURCE: NATIONAL BANK OF MOLDOVA DATABASE, 2009-20I3

The danger is now that the banks' internal risk management systems are not good enough to preempt nonperforming lending. In this context, it would be useful for the National Bank of Moldova to develop an early warning system that would signal any emerging macroprudential risks to the financial system.

\section{Profitability}

The profitability indicators of the local banking system have been negatively influenced by the global financial crisis. They recorded a sudden drop in 2009: Return On Assets (ROA) decreased by 1.23 percentage points compared with 2008, and Return On Equity (ROE) dropped dramatically by 18.74 percentage points (Figure 8 ). The banking sector ended 2009 with a net loss of 173.0 million lei, although some banks made profits even in that year. In 2010, the banking sector recovered from the crisis, due to the recovery of the national economy. Although affected by the crisis in 2008 and 2009, rapid recovery of domestic consumption was the first and main impetus for economic growth in 2010 . 
Figure 8. ROA and ROE of the banking system of the Republic of Moldova (\%), 2006-2013

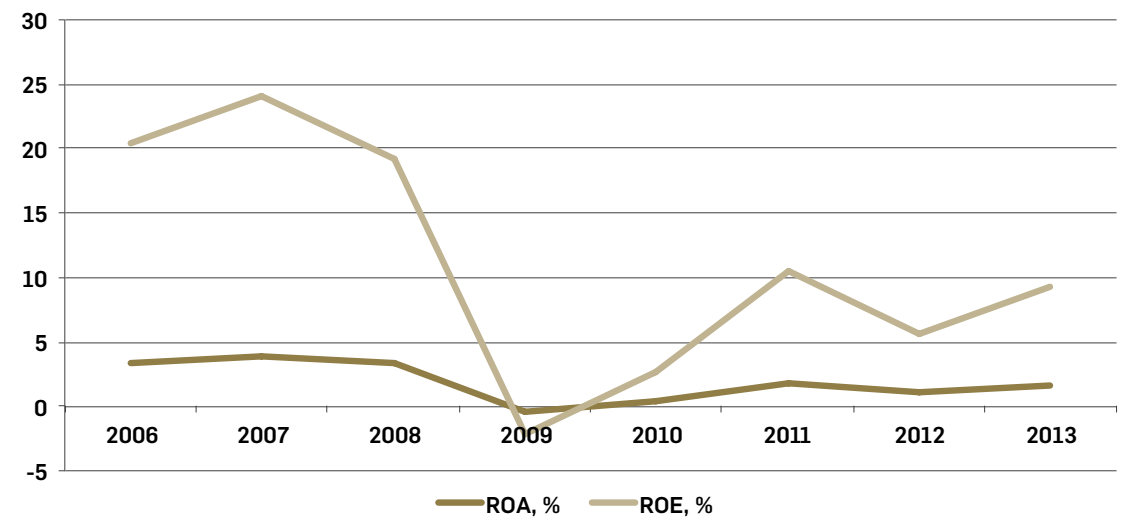

SOURCE: NATIONAL BANK OF MOLDOVA DATABASE, 2006-2013

In 2012, due to the indirect effects of the sovereign debt crisis, profitability indicators decreased again. In 2013, the banking efficiency indicators recorded an increase compared to the previous year: ROA by 0.5 percentage points and ROE by 3.7 percentage points.

\subsection{Evolution of the structural development indicators}

The statistical data (Figure 9) suggest that the local banking system's level of concentration has slowly increased since 2008.

Figure 9. Structural indicators of the Republic of Moldova's banking system, at year-end

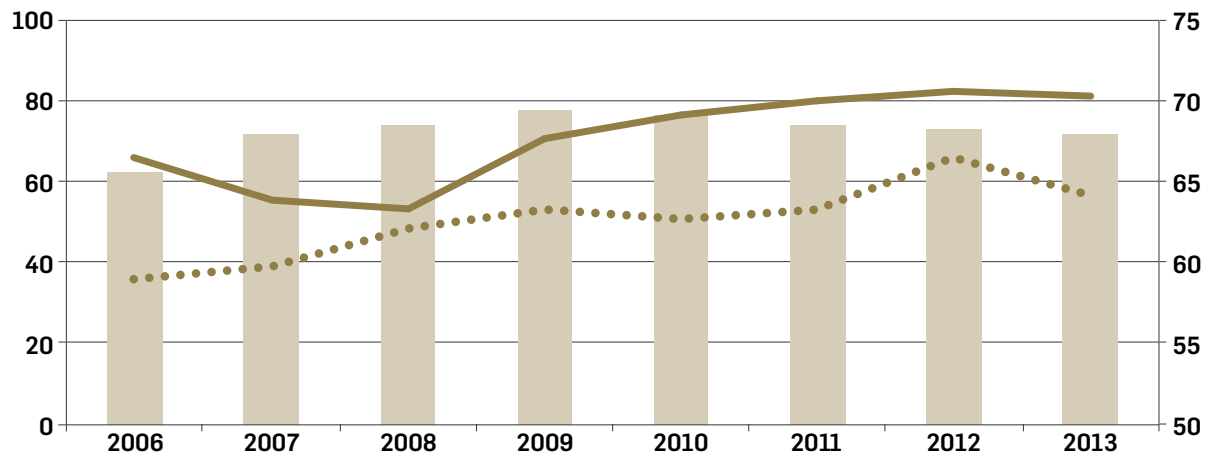

Share of foreign investments in banking capital (\%)

- Assets of the 5 largest banks by assets size/total banking assets, \% (secondary axis)

-.. Total regulatory capital of the 5 largest banks by capital size/total banking regulatory capital, \% (secondary axis) 
It is a result of the movement of bank clients toward the biggest banks of the system with higher visibility. Since 2008, two small banks from sixteen have been hit hard by the crisis and become insolvent, as a result of unsatisfactory management of the banks. It could be concluded that in the case of the Republic of Moldova, as with Canada and Australia, a more concentrated financial system is more resilient to financial distress, and the biggest banks have a greater capacity to face risks, due to higher capitalization and liquidity (OECD, 2010).

Despite the crisis, foreign participation in the local banking industry increased from $62.7 \%$ in 2006 to $75.1 \%$ in 2013 . However, due to the low transparency of Moldovan banking capital, it is quite difficult to assess the foreign investment situation. The presence of foreign strategic investors is considerably lower than in other countries.

While those owners who have more than a $5 \%$ stake in a bank have been mostly found to be fit and proper, the ability and willingness of such owners to provide know-how and capital or liquidity support is not clear. On the other hand, the limited presence of foreign banks in the local banking market has protected it from the contagious effects of the crisis. However the investments of first-tier banks in Moldova are welcome. The main arguments for this are the implementation of highly-efficient risk management practices within the local banking system and the injection of long-term financial resources into the Moldovan economy. The supervisors should continue to exert pressure on the banks to consolidate ownership in individual banks through strategic investors. Uncertainties in ownership structure still contribute to vulnerability despite the considerable efforts of the $\mathrm{NBM}^{7}$. The process of clarifying the ultimate beneficial owners has not been completed. This raises concerns in relation to large exposures, connected lending, and loan concentration, and in establishing whether the owner can provide contingency funds in case of a bank run or other stress situations.

The likelihood of a financial crisis is lower in countries where regulation allows more entry, foreign ownership and a wider range of activities, and where the institutional conditions stimulate competition. Levine et al. (1998) find that the presence of foreign banks is associated with a lower risk of banking crisis. A greater foreign bank presence may lead to greater banking efficiency and competition in the domestic financial system. Empirical studies have shown that by improving overall operating efficiency, foreign entry helps create the conditions for better financial intermediation and longterm growth (Claessens et al., 2001). On the other hand, in terms of self-protection,

\footnotetext{
7 The threshold for significant shareholding was reduced to 5 percent from the previous level of 10 percent. Banks are obliged to submit information on their shareholders exceeding this limit. In case of noncompliance, the NBM limits the operations of the banks that do not support the enforcement of the regulation. In addition, the NBM requires that information be provided on shareholders with holdings between $I$ and 5 percent. This requirement attempts to prevent connected parties from circumventing the regulation by splitting holdings into portions not exceeding 5 percent.
} 
foreign banks might run away at the first signs of trouble, and in this way they may introduce a new source of contagion. This remains to be a supposition which should be verified empirically.

The impact of the global financial crisis can be noted in the number of borrowers of commercial banks per 1,000 adults ${ }^{8}$. This indicator reflects the financial access to and usage of banking services, which declined significantly from 64 borrowers per 1,000 adults in 2008, to 37 in 2011. A positive trend is noted in the number of commercial bank depositors per 1,000 adults ${ }^{9}$, increasing from 789 in 2004 to 1166 in 2011 (Figure 10). This shows increasing public confidence in local commercial banks.

Figure 10. Number of borrowers and depositors of Moldovan commercial banks per 1000 adults, between 2004 and 2011

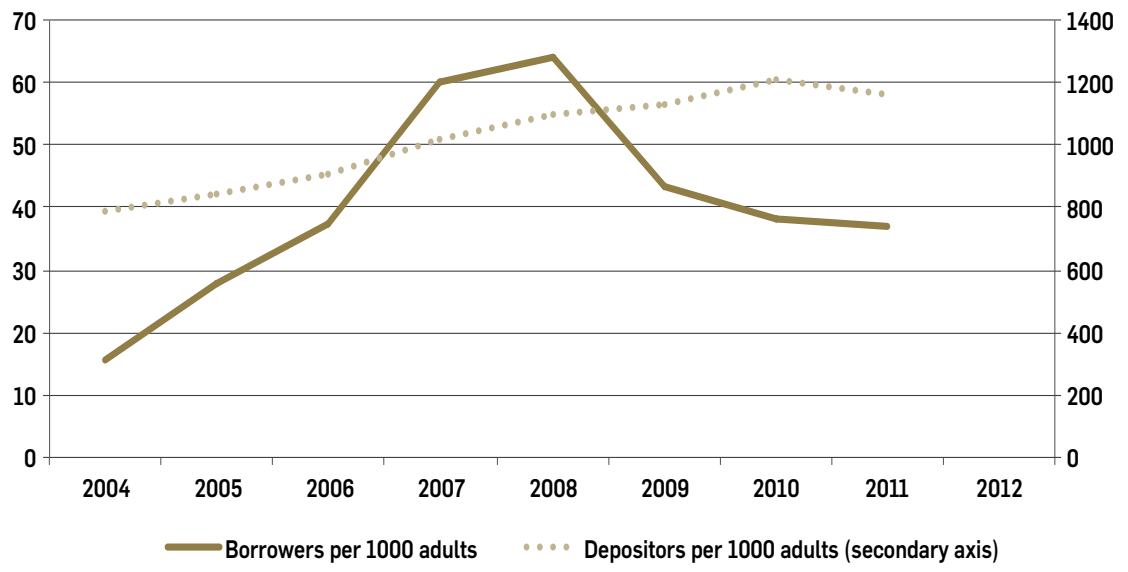

SOURCE: COMPILED BY THE AUTHORS USING DATA FROM IMF FINANCIAL ACCESS SURVEY

Credit activity is still restricted in comparison with the countries of Central and Eastern Europe, where opened credit accounts at commercial banks reached 492 accounts in 2011 (per 1,000 adults), compared to 46 accounts open in Moldova. Also, banking accessibility indicators are close to CIS indicators, but there is a big gap in comparison to Central and Eastern European countries ${ }^{10 .}$

The impact of the global financial crisis was felt in terms of the degree of financial intermediation (financial depth indicators) in the Republic of Moldova (2009-2010). Financial depth approximated by private credit-to-GDP, has a strong statistical link to long-term economic growth; it is also closely linked to poverty reduction.

\footnotetext{
${ }^{8}$ Calculated as: (number of depositors)*I,000/adult population in the reporting country.

${ }^{9}$ Calculated as: (number of borrowers)*I,000/adult population in the reporting country.

${ }^{10}$ IMF Financial Access Survey http://fas.imf.org/.
} 
The dynamic growth of loans granted to the private sector (20-30\% annually) up to 2008 , contributed to GDP reaching a value of $39.4 \%$ that year, after the damage inflicted by the financial crisis on the portfolio quality of bank loans and a slight decline for two consecutive years. During 2012, this indicator increased from $37.2 \%$ to $39.8 \%$, due to an increase in gross loan portfolio (according to prudential reports) that year (NBM, 2012). This fact demonstrates that the banking system continues gradually to increase its influence on the development of the real economy. Despite the achievements in this field, access to finance continues to be identified as one of the main constraints on the development of Moldovan companies (World Bank, 2013).

The share of bank assets in Moldova's GDP increased overall between 2006 and 2012, from $50.8 \%$ to $66.4 \%$, but due to the crisis it decreased by 7.3 percentage points in 2010 . The share of assets in GDP had increased from 59.8\% at the end of 2011 to $66.4 \%$ at the end of 2012, due to a faster qrowth of bank assets in comparison with GDP.

\section{Figure 11. Dynamics of assets, loans and deposits to GDP on} banking sector (\%), at year-end

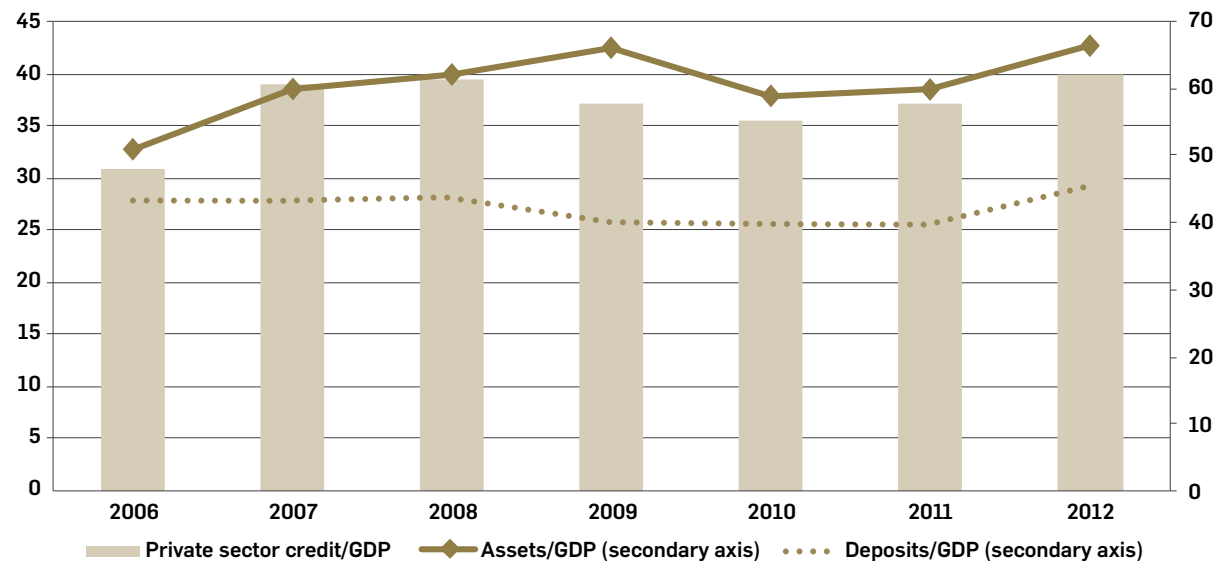

SOURCE: NBM DATABASE, 2006-2012

The share of deposits in GDP remained between the values of $43.3 \%$ and $45.3 \%$ in the analyzed period, with an insignificant decrease in 2009. In 2012, this indicator increased significantly by 5.5 percentage points, representing $45.3 \%$ of GDP and surpassing such countries as Romania, Hungary, Lithuania and Latvia. This positive evolution is due to a rise in the total amount of attracted deposits of $21.6 \%$ compared to January 2012. Individuals' deposits increased by $23 \%$, corporate deposits by $20.2 \%$ and bank deposits by $10.9 \%$.

A comparative analysis of financial intermediation shows that Moldova is currently ranked alongside regional countries at similar stages of development (surpassing 
countries such as Georgia, Belarus, Armenia), but below the EU average (see appendix B). According to this data, private credit-to-GDP differs widely across countries and correlates strongly with income level. For example, private credit to GDP in high-income countries is more than four times the average ratio in lowincome countries. However, a very high ratio of private sector credit to GDP is not necessarily a good thing. For example, all eight countries with the highest ratios of private sector credit to GDP as of 2010 (from highest to lowest: Cyprus, Ireland, Spain, Netherlands, Portugal, United Kingdom, Luxembourg, and Switzerland) have experienced a major crisis episode since 2008.

\section{Conclusions}

In recent years, the Moldovan banking system has demonstrated a high degree of resilience to the global financial crisis. This resilience of the local banking system was determined by several factors:

a) The Republic of Moldova's banking system has a high degree of capitalization and liquidity, factors which contribute to and maintain the general stability of the entire financial system. The average capital adequacy ratio of Moldova's banking system recorded for 2009-2012 (29.2\%) indicates a high degree of bank safety and the ability to perform risky operations without affecting the capital.

b) Moldovan banks demonstrate a high level of resilience due to their funding structure. They finance themselves mostly with depository funding instead of wholesale funding. This preference diminishes substantially the risks of contagion in the banking system. The deposits-to-liabilities ratio reached $85.4 \%$ at year-end 2013 , much of which came from retail sources. On the other hand, this makes banks susceptible to other risks; if many depositors want to withdraw deposits at the same time (depositor runs on the bank) and the bank does not have enough cash on hand, the banks can become illiquid. However, taking into consideration the high level of liquidity in the Moldovan banking system and high level of required reserves at the central bank (a minimum level of $14 \%$ of attracted resources that a licensed bank is required to maintain with the National Bank of Moldova), the possibility of such risks arising is very low.

c) Concentration ratios of the Moldovan banking system are relatively high, ranging between 60 and 70\% for the five largest banks in the system. There is evidence to suggest that concentrated banking systems tend to have larger, better-diversified banks, which may help account for the positive link between concentration and stability. 
d) A comparative analysis of financial intermediation shows that Moldova is currently ranked alongside regional countries at similar stages of development (surpassing countries such as Georgia, Belarus, Armenia), but below the EU average. Countries with the highest ratios of private sector credit to GDP have experienced a major crisis episode since 2008.

The local banking system has a low degree of connectivity to the European and world banking systems due to the limited presence of international banks in the market. This has meant that there has been no direct contagion in the last financial crises. The effects of the crises in Moldova were felt indirectly by the banks, through the channel of remittances and foreign trade, which have diminished substantially as a result of the economic decline in Europe, particular in 2009.

However the main implications of the recent financial crisis on the local banking system are the following:

a) Economic contraction in 2009 due to the global financial crisis caused a significant increase in nonperforming loans (substandard, doubtful and loss) as a percentage of the total loan portfolio, from $5.9 \%$ in 2008 to $16.3 \%$ in 2009.

b) The profitability indicators of the local banking system have been negatively influenced by the global financial crisis. They recorded a sudden drop in 2009: ROA decreased by 1.23 percentage points compared with 2008, and ROE dropped dramatically by 18.74 percentage points.

c) The impact of the global financial crisis was felt in terms of the degree of financial intermediation (financial depth indicators). As a result of the financial crisis, private sector credit to GDP decreased for two consecutive years - 2009 and 2010.

The high degree of resilience of the Moldovan banking system to the recent financial crisis, however, does not demonstrate a high degree of banks' involvement in the development of the real economy. Because of this the intermediation function of Moldovan commercial banks is undermined (i.e. compromised, weaken). Although the level of liquidity in the system is one of the largest in the region they are very cautious in granting loans. The root cause of this undermining is the mutual crisis of confidence: of the individuals and companies towards banks, and of commercial banks towards potential borrowers. It explains the conservative approach of local banks' risk management, the reluctance in their lending activity and the maintenance of a high level of liquidity. This conservative approach has become even more acute during the recent economic crisis. It reveals that lack of resources is not the essential issue in passive lending, and high levels of liquidity may be a consequence of this reluctance with regards to credit activity. 


\section{References}

Calomiris, C.W. (2009). Banking Crises Yesterday and Today, Working Paper, Columbia Business School, New York.

Claessens, S., Demirguc-Kunt, A. and Huizinga, H. (2001). How does foreign bank entry affect domestic banking markets?, Journal of Banking and Finance, 25, pp. 891-911.

Contessi, S. and El-Ghazaly, H. (2011). Banking crises around the world: different governments, different responses, The Regional Economist. Available at: www.stlouisfed.org/publications/re/articles/?id=2096 [Accessed 8 January 2014]

Davis, E.P. (1995). Debt, Financial Fragility, and Systemic Risk, Oxford University Press, Oxford and New York.

Degryse, H., Elahi, M.A. and Penas, M.F. (2013). Determinants of Banking system fragility a regional Perspective, ECB, Working Paper Series No. 1567, July.

Demirgüç-Kunt, A. and Detragiache, E. (2005). Cross-Country Empirical Studies of Systemic Bank Distress: A Survey, IMF Working Paper, No. 05/96

Drees, B. and Pazarbasioglu, C. (1998). The Nordic banking crises: pitfalls in financial liberalization?, IMF Working Paper No. 161, Washington, DC.

García-Herrero, A. (1997). Banking crisis in Latin America in the 1990s: Lessons from Argentina, Paraguay, and Venezuela. IMF Working Paper No. 40.

Gavin, M. and Hausman, R. (1995). The roots of banking crises: the macroeconomic context. In R. Hausman and L. Rojas-Suárez (Eds.), Banking Crises in Latin America, John Hopkins University Press, Baltimore.

Global Finance (2013). Country Economic Reports \& GDP Data, Moldova. Available at: www.gfmag.com/gdp-datacountry-reports/219-moldova-gdp-country-report.html\#axzz2xA8D4hJ7 [Accessed 7 March 2014]

Goldstein, M. and Turner, P. (1996). Banking crises in emerging economies: origins and policy options, BIS Economic Paper No. 46, October.

González-Hermosillo, B., Pazarbasioglu, C. and Billings, R. (1997). Determinants of banking sector fragility: a case study of Mexico, IMF Staff Papers, September.

Jaramillo, J.C. (2000). An overview of Paraguay's banking crisis during the 1990s'. Mimeo, International Monetary Fund.

Kaminsky, G.L., Reinhart, C.M. (1999). The Twin Crises: The Causes of Banking and Balance-of-Payments Problems, American Economic Review, 89(3), pp. 473-500.

Laeven, L. and Valencia, F. (2012). Systemic Banking Crises Database: An Update, IMF Working Paper No. 12/163, June. Available at: www.imf.org/external/pubs/ft/wp/2012/wp12163.pdf [Accessed 10 February 2014]

Levine R., Demirguc-Kunt, A. and Min, G.H. (1998). Opening to foreign banks: issues of stability, efficiency, and growth, in S. Lee (Ed.), The Bank of Korea, Seoul.

Mishkin, F.S. (1996). Understanding financial crises: a developing country perspective, NBER Working Paper No. 5600, Cambridge MA.

NBM (2012). Annual report. Available at: https://bnm.md/md/annual_report [Accessed 15 February 2014]

OECD (2010). Concentration and Stability in the Banking Sector, DAF/COMP 2010(9), Roundtable on competition, concentration and stability in the banking sector, Organization for Economic Co-operation and Development.

Ramos, A. (1998). Capital structures and portfolio composition during banking crisis - lessons from Argentina 1995, IMF Working Paper 98/121. 
Rojas-Suárez, L. and Weisbrod, S. (1995). Financial Fragilities in Latin America, IMF Occasional Paper No. 132.

Sheng, A. (1995). Bank restructuring, The World Bank, Washington DC.

Schumacher, L. (2000). Bank runs and currency runs in a system without a safety net, Journal of Monetary Economics, 46(1), pp. 257-77.

World Bank (2013). Migration and Development Brief, World Bank, Washington DC. Available at: http://www.worldbank.org/en/news/press-release/2013/04/19/world-bank-launches-initiative-on-migration-releases-new-projections-on-remittance-flows [Accessed 18 March 2014]

World Bank (2013). Enterprise Access to Finance Background Note, Vol. 2 of Moldova - Policy priorities for private sector development, World Bank, Washington DC. Available at: www.ebrd.com/pages/research/economics/ data/macro.shtml [Accessed 10 March 2014]

\section{Appendix A.}

Market share of the commercial banks in the Republic of Moldova

\begin{tabular}{|c|c|c|c|c|c|c|c|}
\hline \multirow[t]{2}{*}{ No } & \multirow[t]{2}{*}{ Bank name } & \multicolumn{2}{|c|}{$\begin{array}{c}\text { Market share by assets } \\
(\%)\end{array}$} & \multicolumn{2}{|c|}{$\begin{array}{c}\text { Market share by loans } \\
(\%)\end{array}$} & \multicolumn{2}{|c|}{$\begin{array}{l}\text { Market share by } \\
\text { deposits (\%) }\end{array}$} \\
\hline & & 30.06 .2012 & 30.06 .2013 & 30.06 .2012 & 30.06 .2013 & 30.06 .2012 & 30.06 .2013 \\
\hline \multicolumn{8}{|c|}{ Large banks } \\
\hline 1 & B.C. "VICTORIABANK" S.A. & 17.8 & 17.8 & 15.7 & 17.8 & 22.0 & 21.1 \\
\hline 2 & $\begin{array}{l}\text { B.C. "MOLDOVA - } \\
\text { AGROINDBANK" S.A. }\end{array}$ & 19.1 & 19.2 & 22.0 & 21.4 & 18.2 & 19.3 \\
\hline 3 & B.C. "Moldindconbank" S.A. & 13.7 & 15.7 & 14.6 & 18.1 & 15.0 & 16.7 \\
\hline 4 & Banca de Economii S.A. & 12.4 & 9.0 & 8.1 & 4.6 & 13.7 & 10.0 \\
\hline \multicolumn{8}{|c|}{ Medium banks } \\
\hline 1 & $\begin{array}{l}\text { B.C. "EXIMBANK - } \\
\text { Gruppo Veneto Banca" S.A.) }\end{array}$ & 7.7 & 7.4 & 8.8 & 8.0 & 5.5 & 4.9 \\
\hline 2 & $\begin{array}{l}\text { B.C. "MOBIASBANCÁ - } \\
\text { Groupe Societe Generale" S.A. }\end{array}$ & 6.1 & 5.7 & 6.0 & 6.1 & 5.6 & 5.1 \\
\hline 3 & B.C. "BANCA SOCIALĂ" S.A. & 6.0 & 6.2 & 7.1 & 6.5 & 5.9 & 6.5 \\
\hline 4 & B.C. "ProCredit Bank" S.A. & 4.6 & 4.7 & 5.9 & 5.9 & 2.0 & 3.1 \\
\hline 5 & B.C. "ENERGBANK" S.A. & 3.2 & 2.9 & 3.1 & 2.7 & 3.3 & 2.9 \\
\hline 6 & B.C. "UNIBANK" S.A. & 2.2 & 5.2 & 1.6 & 3.4 & 2.2 & 5.2 \\
\hline 7 & "FinComBank" S.A. & 3.1 & 2.7 & 2.9 & 2.5 & 3.0 & 2.4 \\
\hline \multicolumn{8}{|c|}{ Small banks } \\
\hline 1 & B.C.R. Chişinău S.A. & 2.3 & 1.6 & 2.3 & 1.5 & 1.7 & 1,1 \\
\hline 2 & B.C. "COMERŢBANK" S.A. & 1.2 & 1.4 & 1.3 & 1.1 & 1.2 & 1.5 \\
\hline 3 & B.C. "EuroCreditBank" S.A. & 0.7 & 0.5 & 0.6 & 0.4 & 0.4 & 0.2 \\
\hline & rfindahl-Hirschman Index (points) & 1207,3 & 1207.6 & 1238.5 & 1330.9 & 1360.3 & 1341.8 \\
\hline & 2-411 (\%) & 63.0 & 61.7 & 61.1 & 65.3 & 68.9 & 67.1 \\
\hline
\end{tabular}

\footnotetext{
${ }^{11}$ Four-Banks Concentration Ratio - measures the total market share of the four largest banks in the banking system.
} 
Appendix B.

The degree of financial intermediation group of some EU and CIS countries, 2012

\begin{tabular}{|c|c|c|c|}
\hline & Assets to GDP (\%) & Credits to GDP (\%) & Deposits to GDP (\%) \\
\hline \multicolumn{4}{|l|}{ EU countries } \\
\hline Austria & 336.4 & 114.4 & 105.2 \\
\hline Bulgaria & 109.6 & 70.8 & 65.8 \\
\hline Czech Republic & 116.5 & 51.7 & 68.6 \\
\hline Estonia & 119.1 & 84.5 & 58.4 \\
\hline France & 420.7 & 104.4 & 93.7 \\
\hline Germany & 326.5 & 100.1 & 120.2 \\
\hline Greece & 221.7 & 115.5 & 83.7 \\
\hline Italy & 257.6 & 109.8 & 87.7 \\
\hline Latvia & 146.9 & 81.1 & 40.2 \\
\hline Lithuania & 80.4 & 52.1 & 39.0 \\
\hline Netherlands & 402.4 & 168.7 & 142.3 \\
\hline Poland & 83.7 & 49.7 & 47.3 \\
\hline Portugal & 335.4 & 157.2 & 136.2 \\
\hline Slovakia & 84.0 & 49.9 & 55.2 \\
\hline Slovenia & 147.1 & 89.1 & 59.9 \\
\hline Spain & 337.4 & 168.4 & 156.5 \\
\hline Hungary & 113.9 & 56.2 & 43.9 \\
\hline Romania & 67.9 & 38.6 & 32.4 \\
\hline UE27 & 366.7 & 121.4 & 113.6 \\
\hline \multicolumn{4}{|l|}{ Some CIS countries } \\
\hline Georgia & $51.4^{*}$ & 35.0 & $32.5^{\star}$ \\
\hline Belarus & 60.9 & 32.2 & 24.2 \\
\hline Azerbaijan & 67.4 & 24.7 & 19.5 \\
\hline Ukraine & 80.0 & 80.2 & 39.6 \\
\hline Armenia & 62.2 & 44.2 & 21.5 \\
\hline Moldova & 66.4 & 42.2 & 45.3 \\
\hline Russian Federation & 79.1 & - & 38.1 \\
\hline
\end{tabular}

* Georgia statistical data refers to end of 2011 .

SOURCE:WORLD BANK AND ECB (STATISTICAL DATA WAREHOUSE) 